\title{
Zrobotyzowane spawanie hybrydowe Plazma+MAG stali S700 MC
}

\section{Robotic hybrid Plasma+MAG welding of S700 MC steel}

\section{Streszczenie}

W artykule opisano zrobotyzowane stanowisko hybrydowe Plazma+MAG. Przedstawiono wstępne wyniki badań złączy spawanych stali obrabianej termomechanicznie o wysokiej granicy plastyczności S700 MC o grubości $10 \mathrm{~mm}$ z materiałem dodatkowym. Przeprowadzono badania nieniszczące złączy świadczące o poziomie jakość złącza B wg ISO 12932. Wykonano badania metalograficzne, opisano mikrostrukturę złączy oraz scharakteryzowano twardość w charakterystycznych obszarach złączy. Zmierzono twardość w strefie wpływu ciepła złączy wykonanych z różną energią liniową spawania.

Słowa kluczowe: spawanie hybrydowe, S700 MC, stal o wysokiej granicy plastyczności

\section{Abstract}

The article presents the robotic hybrid Plasma+MAG welding system. The Single pass butt weld $10 \mathrm{~mm}$ thickness joints of steel S700 MC with filler material has been welded. Preliminary results of joints properties has been presented. Mettalographic studies were describe microstructure of the welded joints and its hardness in specific areas. It was measured hardness in the heat affected zone of the joints obtained of different heat input welding.

Keywords: hybrid welding, S700 MC, high strength steel

\section{Wstęp}

W obrębie technologii materiałowych ma miejsce ciągły rozwój polegający na wprowadzaniu nowych rozwiązań oraz ulepszaniu już istniejących. Generalnie dąży się do zwiększenia wydajności produkcji z jednoczesnym zmniejszeniem kosztów wytwarzania. Coraz częściej podczas łączenia metali i ich stopów zastosowanie znajdują procesy spawania będące efektem łączenia kilku metod obróbki [1,2], które umożliwiają uzyskanie wysokiej jakości złączy spawanych przy zapewnieniu wysokiej efektywności procesu łączenia oraz obniżeniu nakładu pracy. Kompozycja metod ukierunkowana jest na wykorzystanie pozytywnych indywidualnych cech obu metod z jednoczesnym eliminowaniem ich ograniczeń w hybrydzie. Ten kierunek rozwoju doprowadził do udoskonalania istniejących już metod spawania, czego rezultatem było wypromowanie pod koniec XX wieku idei spawania hybrydowego. Spawanie hybrydowe jest połączeniem dwóch różnych spawalniczych źródeł ciepła, w tym przypadku swobodnie jarzącego się łuku elektrycznego $w$ metodzie MAG oraz wysoce zjonizowanej plazmy. Plazma kojarzona jest w wysoką wydajnością stapiania [3] lecz wymaga precyzyjnego przygotowania brzegów podczas spawania z kanałem parowym. Zastosowanie kombinacji tych metod spawania umożliwiło wykorzystanie ich zalet w jednym procesie spawania. W efekcie uzyskano wysoką koncentrację ciepła w miejscu łączonych elementów, z charakterystyczną dla MAG stosunkowo szeroką tolerancją przygotowania brzegów

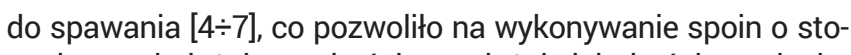
sunkowo niedużej szerokości oraz dużej głębokości wtopienia. Aby w pełni wykorzystać wysoką wydajność spawania nowej metody niezbędnym jest zastosowanie zrobotyzowanego, szybkiego manipulowania hybrydowym plazmotronem. Obserwowany jest efekt synergicznego oddziaływania dwóch źródeł ciepła, procesy wzajemnie się stabilizują, umożliwiając uzyskanie większej prędkości spawania niż dla klasycznego procesu spawania plazmowego. Uzyskuje się znaczne zwiększenie wydajności procesu spawania (mierzonej masą powstającego stopiwa w czasie), nie tylko poprzez zwiększenie prędkości spawania, ale także poprzez brak lub znaczne ograniczenie ukosowania krawędzi łączonych blach i zmniejszenie odkształceń w spawanych elementach (skrócenie czasu na prostowanie konstrukcji). Proces spawania hybrydowego może być szczególnie przydatny $\mathrm{w}$ wielkogabarytowej produkcji przemysłowej ze względu na stosunkowo wysoką (w odniesieniu do spawania laserowego) tolerancję w przygotowaniu elementów do spawania, możliwość łączenia blach w jednym przejściu oraz wymaganą niższą dokładność we wzajemnym ustalaniu pozycji łączonych blach.

\section{Materiał rodzimy stal S700 MC}

W ostatnich latach obserwuje się wzrost udziału w rynku konstrukcji spawanych wykonanych ze stali o podwyższonej

Mgr inż. Jacek Szulc - SupraElco, dr hab. inż. Tomasz Chmielewski, prof. PW - Politechnika Warszawska, mgr inż. Zbigniew Pilat - Przemysłowy Instytut Automatyki i Pomiarów.

Autor korespondencyjny/Corresponding author. jacek.szulc@supraelco.waw.pl 
Tablica I. Skład chemiczny i właściwości mechaniczne stali walcowanej termomechanicznie S700MC wg PN EN 10149-2 Table I. The Chemical composition of S700MC steel after thermomechanical treatment according to PN EN 10149-2

\begin{tabular}{|c|c|c|c|c|c|c|c|c|c|c|c|}
\hline \multicolumn{12}{|c|}{ Stężenie pierwiastków, \% } \\
\hline $\begin{array}{c}\mathrm{C} \\
\max \end{array}$ & $\begin{array}{c}\mathrm{Si} \\
\max \end{array}$ & $\begin{array}{c}\text { Mn } \\
\max .\end{array}$ & $\begin{array}{c}\mathrm{P} \\
\max \end{array}$ & $\begin{array}{c}\mathrm{S} \\
\max \end{array}$ & $\begin{array}{l}\mathrm{Al}_{\text {calk }} \\
\mathrm{min}\end{array}$ & $\begin{array}{l}\mathrm{Nb} \\
\mathrm{max}^{*}\end{array}$ & $\begin{array}{c}\mathrm{V} \\
\max \end{array}$ & $\begin{array}{c}\mathrm{Ti} \\
\max .\end{array}$ & $\begin{array}{l}\mathrm{B} \\
\max \end{array}$ & $\begin{array}{l}\text { Mo } \\
\max .\end{array}$ & $\begin{array}{l}\mathrm{Ce}^{\star *} \\
\max \end{array}$ \\
\hline 0,12 & 0,60 & 2,10 & 0,008 & 0,015 & 0,015 & 0,09 & 0,20 & 0,22 & 0,005 & 0,50 & 0,61 \\
\hline \multicolumn{12}{|c|}{ Własności mechaniczne } \\
\hline \multicolumn{3}{|c|}{$\begin{array}{c}\text { Wytrzymałość na rozciąganie } \\
\text { Rm, Mpa }\end{array}$} & \multicolumn{3}{|c|}{$\begin{array}{c}\text { Granica plastyczności } \\
\mathrm{Re}, \mathrm{MPa} \\
\end{array}$} & \multicolumn{3}{|c|}{$\begin{array}{l}\text { Wydłużenie } \\
\mathrm{A}_{5} \%\end{array}$} & \multicolumn{3}{|c|}{$\begin{array}{l}\text { Udarność, } \\
\mathrm{J} / \mathrm{mc}^{2}\left(-20^{\circ} \mathrm{C}\right)\end{array}$} \\
\hline \multicolumn{3}{|c|}{822} & \multicolumn{3}{|c|}{768} & \multicolumn{3}{|c|}{19} & \multicolumn{3}{|c|}{135} \\
\hline
\end{tabular}

i wysokiej granicy plastyczności. Wymagania jakościowe stawiane w takich gałęziach przemysłu, jak: stoczniowy, budowy dróg i mostów, hydroenergetyki i energetyki jądrowej, konstrukcji platform wiertniczych, rurociągów oraz maszyn budowlanych sprawiły, że opracowano i wdrożono nowe technologie w dziedzinie metalurgii stali oraz obróbki plastycznej i cieplnej umożliwiające uzyskanie finalnych wyrobów w postaci blach i rur o wysokiej wytrzymałości bez obniżenia ich właściwości plastycznych. Od kilku lat z powodzeniem opracowywane są procesy spawania stali obrabianych termomechanicznie,

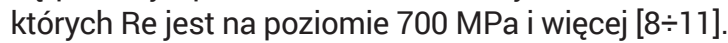

Zastosowanie w konstrukcjach spawanych stali obrabianych termomechanicznie o wysokiej granicy plastyczności i stosunkowo niskim równoważniku węgla umożliwia znaczne ograniczenie czasu wykonywania prac spawalniczych przez obniżenie temperatury podgrzania wstępnego lub nawet całkowitą rezygnację z tego zabiegu, zmniejszenie przekroju elementów konstrukcyjnych, dzięki czemu konstrukcje spawane o porównywalnej ( $z$ materiałami konwencjonalnymi) nośności mogą charakteryzować się niższą masą. Przydatność stali obrabianych termomechanicznie do wytwarzania konstrukcji spawanych bardzo często zależy od czynników, które do tej pory były uwzględniane w niewielkim stopniu przy ocenie ich spawalności. Istotnym problemem w tej grupie stali jest wpływ mikrododatków stopowych (niobu, wanadu) na spawalność i właściwości połączeń spawanych. Rola mikrododatków w tym przypadku sprowadza się do wytworzenia, w czasie kontrolowanego walcowania, odpowiedniej dyspersji wydzieleń węglików, azotków i węglikoazotków niobu i wanadu podwyższających ich właściwości wytrzymałościowe przez umocnienie wydzieleniowe i ograniczenie wielkości ziarna. Rozdrobnienie ziarna sprzyja również zachowaniu dobrych właściwości plastycznych stali. Badania spawalności ujawniły, że trudności podczas spawania stali obrabianych termomechanicznie dotyczą $\mathrm{w}$ większym stopniu właściwości spoin, a w mniejszym stopniu właściwości SWC. Czynnikiem mogącym mieć wpływ na właściwości spoin stali obrabianych termomechanicznie są niekontrolowane procesy wydzieleniowe faz międzymetalicznych MX (drobnodyspersyjne wydzielenia węglików/węglikoazotków $\mathrm{Nb}(\mathrm{C}, \mathrm{N}), \mathrm{V}(\mathrm{C}, \mathrm{N})$ i innych), które w znacznym stopniu mogą obniżać właściwości plastyczne spoin i odporność na pękanie [11 14]. Warto również zwrócić uwagę na niekorzystny wpływ azotu, który odpowiada za procesy starzenia. Sam materiał rodzimy zawiera wystarczającą ilość aktywnego w stosunku do azotu tytanu i aluminium, które tworzą trwałe i mało rozpuszczalne w austenicie wydzielenia TiN i AIN. Stale konstrukcyjne walcowane termomechanicznie są uznawane za dobrze spawalne ze względu na wysoką czystość metalurgiczną oraz niski równoważnik węgla Ce [12 $\div 14]$. Spotykane w literaturze zalecenia odnośnie spawania stali obrabianych termomechanicznie dotyczą materiału dodatkowego do spawania, ograniczenia wodoru w spoinie dzięki stosowaniu procesów niskowodorowych oraz ograniczenia temperatury podgrzania wstępnego, która powinna być o $50 \div 80^{\circ} \mathrm{C}$ niższa niż w przypadku stali normalizowanych oraz ulepszanych cieplnie i nie powinna przekraczać $100^{\circ} \mathrm{C}$. Uzyskanie spoin o właściwościach zbliżonych do właściwości tych gatunków stali $(\mathrm{Rm}, \mathrm{KV})$ wymaga zastosowania spoiw o wyższej niż w materiale rodzimym zawartości składników stopowych, co wiąże się z podwyższeniem równoważnika węgla oraz możliwością pogorszenia spawalności wskutek niekontrolowanych procesów wydzieleniowych w obszarze spoiny. W konsekwencji w przypadku złączy spawanych stali obrabianych termomechanicznie uzyskuje się spoiny niejednorodne pod względem struktury i składu chemicznego (równoważnik węgla). Skład chemiczny spoiny i wartość równoważnika węgla jest więc wypadkową stopnia wymieszania materiału spawanego i zastosowanego spoiwa [8]. W relacjonowanej w niniejszym artykule pracy poddano badaniom złącza ze stali S700 MC o grubości $10 \mathrm{~mm}$ spawane jednościegowo metodą hybrydową Plazma+MAG w pozycji podolnej z zastosowaniem materiału dodatkowego G 696 M21 Mn4Ni1,5CrMo wg EN-ISO 16834. Skład chemiczny i właściwości stali S700MC przedstawia tablica I.

\section{Proces spawania}

Złącza spawane zostały wykonane na zrobotyzowanym stanowisku w Przemysłowym Instytucie Automatyki i Pomiarów - PIAP w Warszawie, w którego skład wchodzą następujące elementy:

1. Robot przemysłowy KUKA KR 16-2F.

2. Zestaw spawalniczy MIG/MAG z dwoma źródłami TPS 9000 (Fronius), możliwość spawania z natężeniem prądu do 800 A.

3. Plazmotron hybrydowy „Plazma-MIG/MAG" Super Heavy-Duty Super-MIG® (PLT).

4. System sensoryczny TH6D ( Scansonic) umożliwiający określenie położenia złącza spawanego przed spawaniem (off-line) oraz śledzenie spoiny i korekcję on-line trajektorii ruchu robota podczas spawania.

5. Ogrodzenie modułowe.

6. Układ sterowania stanowiska.

7. Stół spawalniczy o blacie $50 \times 800 \times 1200$ mm i wysokości 850-900 mm.

8. System wentylacyjny - urządzenie wentylacyjno-odciągowe Kemper.

Zastosowany robot przemysłowy KR 16-2F firmy KUKA jest to wersja przystosowana do pracy w warunkach podwyższonej temperatury. System hybrydowy Plazma+MAG, model Super Heavy-Duty Super-MIG® firmy PLT, scharakteryzowane 
Tablica II. Parametry spawania

Table II. Welding parameters

\begin{tabular}{|c|c|c|c|c|c|c|}
\hline $\begin{array}{c}\text { Oznaczenie } \\
\text { złącza }\end{array}$ & $\begin{array}{c}\text { Napięcie łuku } \\
\text { plazmowego } \\
\text { [V] }\end{array}$ & $\begin{array}{l}\text { Odległość } \\
\text { dyszy } \\
\text { plazmowej } \\
{[\mathrm{mm}]}\end{array}$ & $\begin{array}{c}\text { Średnica dyszy } \\
\text { plazmowej } \\
\text { [mm] }\end{array}$ & $\begin{array}{c}\text { Natężenie } \\
\text { prądu tuku } \\
\text { plazmowego, } \\
\text { [A] }\end{array}$ & $\begin{array}{c}\text { Natężenie } \\
\text { przepływu } \\
\text { gazu } \\
\text { plazmowego } \\
\text { [l/min] }\end{array}$ & $\begin{array}{c}\text { Prędkość } \\
\text { spawania } \\
\text { [m/min }\end{array}$ \\
\hline $\mathrm{C} 1$ & 30 & 5 & 4 & 350 & 3,5 & 0,55 \\
\hline $\mathrm{C} 2$ & 30 & 5 & 4 & 350 & 3,5 & 0,75 \\
\hline C3 & 30 & 5 & 4 & 350 & 3,5 & 0,75 \\
\hline C4 & 30 & 5 & 4 & 350 & 3,5 & 0,95 \\
\hline C5 & 30 & 5 & 4 & 350 & 3,5 & 1 \\
\hline $\begin{array}{c}\text { Oznaczenie } \\
\text { złącza }\end{array}$ & $\begin{array}{l}\text { Rodzaj łuku } \\
\text { MAG } \\
{[\mathrm{V}]}\end{array}$ & $\begin{array}{c}\text { Natężenie } \\
\text { prądu łuku } \\
\text { MAG } \\
\text { [A] }\end{array}$ & $\begin{array}{c}\text { Napięcie łuku } \\
\text { MAG } \\
\text { [V] }\end{array}$ & $\begin{array}{l}\text { Posuw drutu } \\
\text { elektrodowego } \\
\text { [m/min] }\end{array}$ & $\begin{array}{c}\text { Energia liniowa } \\
\text { spawania, } \\
{[\mathrm{KJ} / \mathrm{mm}]}\end{array}$ & $\begin{array}{l}\text { Odstęp } \\
\text { [mm] }\end{array}$ \\
\hline $\mathrm{C} 1$ & Plus & 272 & 26,3 & 11,3 & 1,93 & 0 \\
\hline $\mathrm{C} 2$ & Plus & 328 & 28,3 & 14 & 1,42 & 1,2 \\
\hline C3 & Plus & 353 & 29,3 & 15,4 & 1,42 & 1,6 \\
\hline $\mathrm{C} 4$ & Plus & 374 & 29,4 & 16,1 & 1,12 & 1,6 \\
\hline C5 & Plus & 369 & 29,3 & 16,6 & 1,07 & 1,6 \\
\hline
\end{tabular}

w publikacji [15]. Hybrydowa głowica spawalnicza zamocowana została na kiści robota, złącza wykonywano w pozycji podolnej na chłodzonej wodą podkładce miedzianej. $\mathrm{Na}$ rysunku 1 pokazano widok stanowiska podczas prób technologicznych w firmie TELESKOP w Kostrzyniu nad Odrą. W tabeli II. zestawiono różne stosowane konfiguracje parametrów spawania oznaczone kolejno symbolami od $\mathrm{C} 1$ do C5 różniące się głównie poziomem energii liniowej spawania. Parametr ten jest kluczowym w kwestii degradacji właściwości materiału podstawowego w SWC. Brzegi spawanych blach ukosowano na $15^{\circ} \mathrm{z}$ progiem wysokości $6 \mathrm{~mm}$.

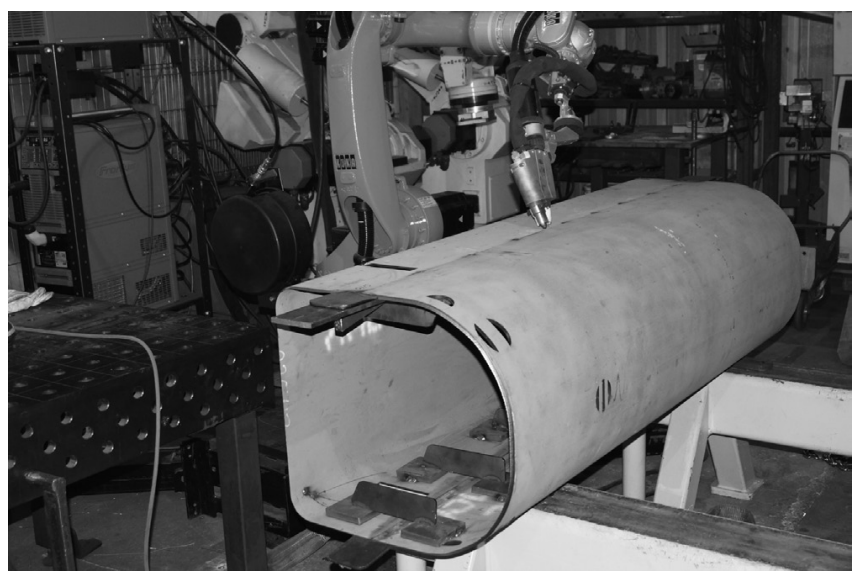

Rys. 1. Widok zrobotyzowanego stanowiska hybrydowego Plazma+MAG, podczas prób technologicznych w firmie TELESKOP

Fig. 1. View of hybride robotic station Plasma+MAG during technology test in company TELESKOP

\section{Badania metalograficzne}

Celem badań było ujawnienie mikrostruktury złącza oraz pomiar twardości obszarów charakterystycznych złączy doczołowych, blach o grubości $10 \mathrm{~mm}$ ze stali S700MC spawanych hybrydowo (plazma - MAG) na podkładce miedzianej.

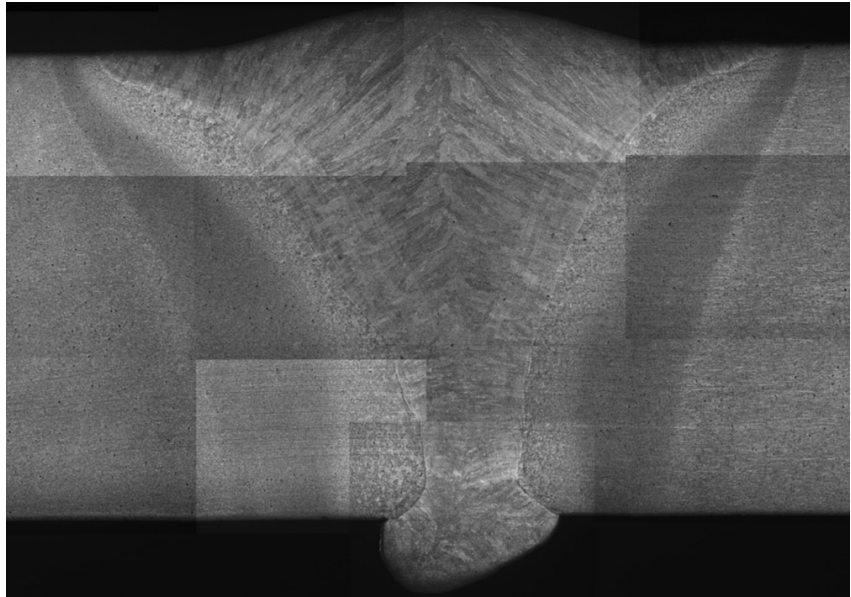

Rys. 2. Mikrostruktura złącza spawanego metodą hybrydową (plazma + MAG) stali S700 MC o grubości $10 \mathrm{~mm}$, wykonanej z energią liniową spawania $1,12 \mathrm{KJ} / \mathrm{mm}$

Fig. 2. Microstructure of S700 MC steel welded joint obtained by hybrid plasma+MAG welding, thickness $10 \mathrm{~mm}$, heat input $1,12 \mathrm{KJ} / \mathrm{mm}$

Badania mikroskopowe w obszarze spoiny ujawniły strukturę bainityczno-ferrytyczną. Obszar strefy wpływu ciepła (SWC) charakteryzuje się zmiennością wielkości ziarna, co spowodowane jest stosunkowo dużą ilością ciepła dostarczoną podczas procesu spawania. Badania mikroskopowe wykazały również obecność wydzieleni węglikowych (najprawdopodobniej azotkowych) w obszarze SWC oraz w materiale rodzimym.

Przeprowadzone pomiary twardości, wykazały że twardość w osi spoiny jest zbliżona do twardości materiału rodzimego i wynosi około $280 \mathrm{HV}_{0,1}$. W SWC dochodzi do obniżenia twardości zależnie od zastosowanej wartości energii liniowej spawania. W próbkach oznaczonych symbolem C4 (tabl.II) spawanych $z$ energią liniową spawania $E_{1}=1,12$ $\mathrm{KJ} / \mathrm{mm}$ najniższa twardość w SWC wynosi około $230 \mathrm{HV}_{0,1}$. Zwiększenie energii liniowej spawania do wartości $E_{1}=1,42$ $\mathrm{KJ} / \mathrm{mm}$ spowodowało uzyskanie najniższej średniej twardość w SWC na poziomie około $200 \mathrm{HV}_{0,1}$. 
Wartość twardości w górnej części spoiny jest zbliżona do twardości materiału rodzimego $\left(280 \mathrm{HV}_{0,1}\right)$ i jest wyższa od wartości zmierzonej w dolnej części spoiny o ok. 5\%. Najprawdopodobniej stan ten może być spowodowany segregacją dodatków stopowych zwiększających hartowność, pochodzących z materiału dodatkowego. Rozkłady twardości w przekroju poprzecznym spoin wykonano metodą mikro Vickersa z obciążeniem wgłębnika masą 100 gr. zgodnie z zaznaczonymi na rysunku 4. liniami pomiarowymi. Na wykresach przedstawiono średnią arytmetyczną twardość obszaru charakterystycznego z zaznaczeniem wartości odchylenia standardowego (przyjęty poziom ufności 95\%).

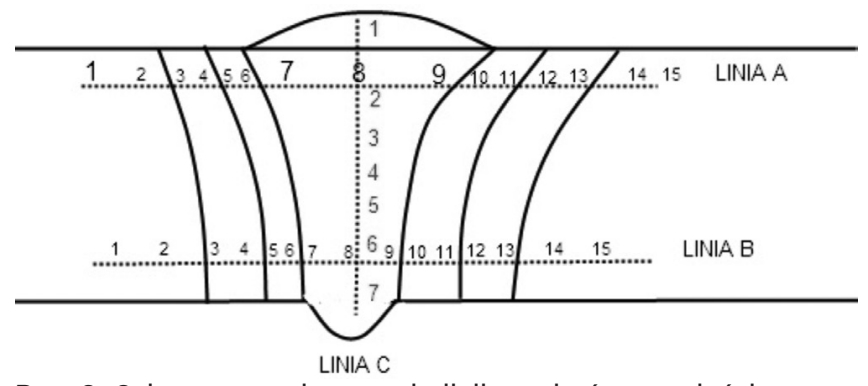

Rys. 3. Schemat rozmieszczenia linii pomiarów twardości w przekroju poprzecznym złączy spawanych

Fig. 3. Hardness measurement lines distribution scheme of the S700 MC steel welded joints

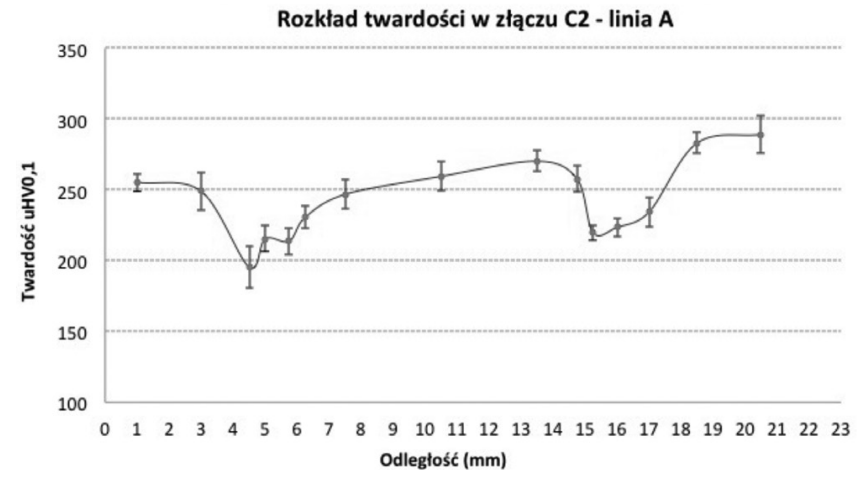

Rys. 4. Rozkład twardości w złączu spawanym $\mathrm{C} 2$ (na linii A wg rys. 4) wykonanym $z$ energią liniową spawania $\mathrm{El}=1,42 \mathrm{KJ} / \mathrm{mm}$

Fig. 4. Hardness distribution in the welded joints $\mathrm{C} 2$ (in line $\mathrm{A}$ according to fig. 4) with heat input to the welding aera $\mathrm{El}=1,42 \mathrm{KJ} / \mathrm{mm}$

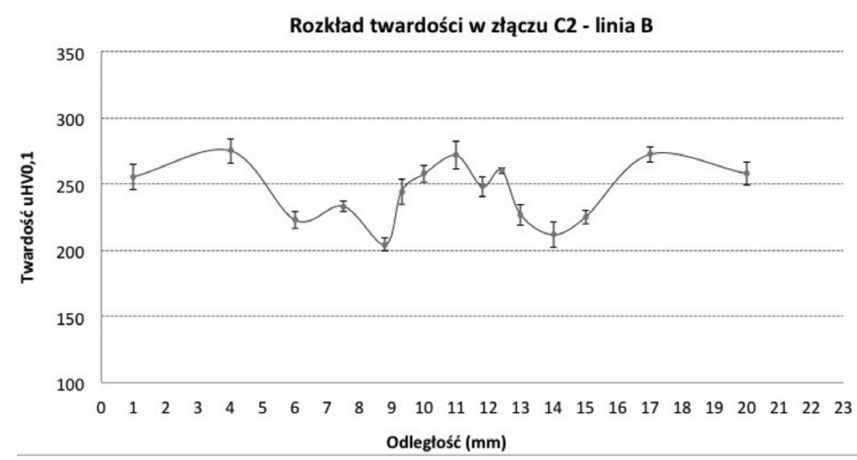

Rys. 5. Rozkład twardości w złączu spawanym C2 (na linii B wg rys. 4) Fig. 5. Hardness distribution in the welded joints $\mathrm{C} 2$ (in line $B$ according to fig. 4)

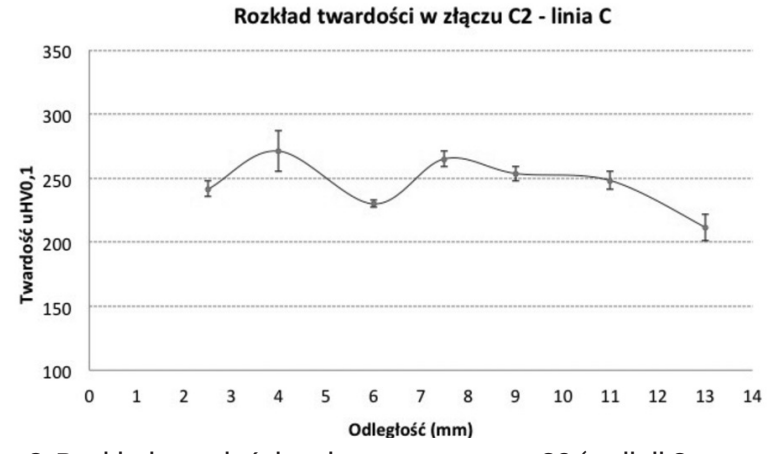

Rys. 6. Rozkład twardości w złączu spawanym C2 (na linii C wg rys. 4) Fig. 6. Hardness distribution in the welded joints $\mathrm{C} 2$ (in line $\mathrm{C}$ according to fig. 4)

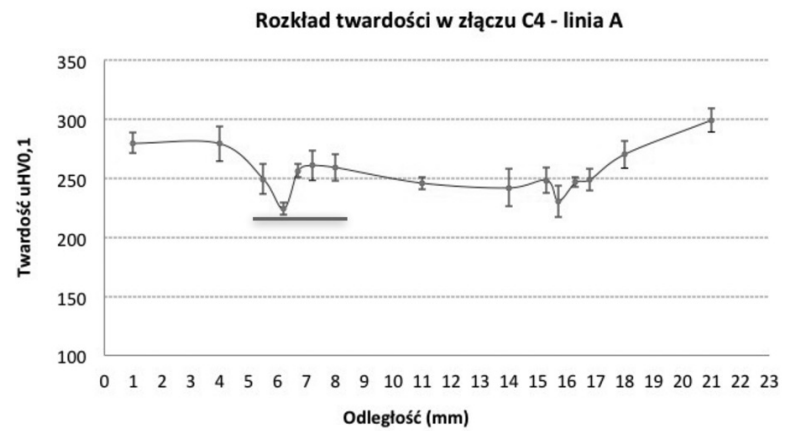

Rys. 7. Rozkład twardości w złączu spawanym C4 (na linii A wg rys. 4) wykonanym $z$ energią liniową spawania $E_{l}=1,12 \mathrm{KJ} / \mathrm{mm}$ Fig. 7. Hardness distribution in the welded joints $\mathrm{C} 4$ (in line $\mathrm{A}$ according to fig. 4) with heat input to the welding aera $E_{l}=1,12 \mathrm{KJ} / \mathrm{mm}$

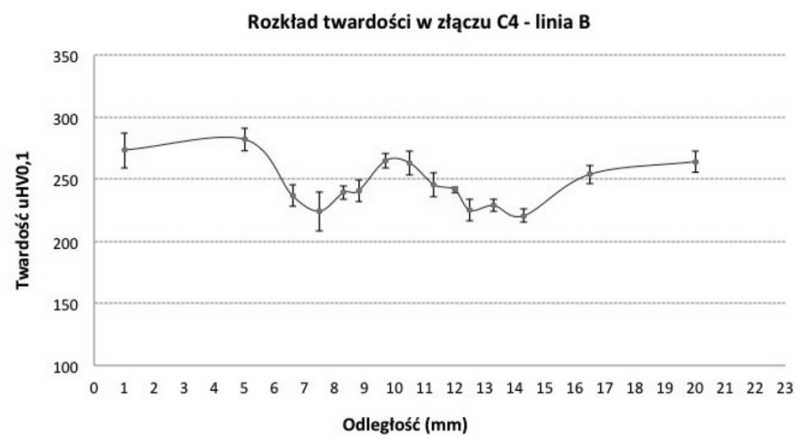

Rys. 8. Rozkład twardości w złączu spawanym C4 (na linii B wg rys. 4) Fig. 8. Hardness distribution in the welded joints $C 4$ (in line B according to fig. 4)

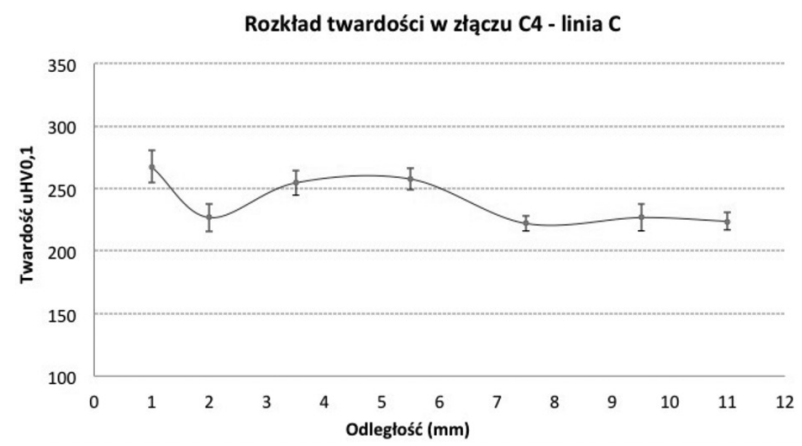

Rys. 9. Rozkład twardości w złączu spawanym C4 (na linii C wg rys. 4) Fig. 9. Hardness distribution in the welded joints $\mathrm{C} 4$ (in line $\mathrm{C}$ according to fig. 4) 


\section{Podsumowanie i wnioski}

Przeprowadzone badania właściwości spoin stali S700 MC o grubości $10 \mathrm{~mm}$, wykonanych metodą hybrydową (plazma+MAG) przy użyciu materiału dodatkowego wstępnie wykazały, że istnieje możliwość wykonania złączy spawanych, spełniających kryteria normy ISO 15614-14. Uzyskane złącza próbne charakteryzowały się brakiem niezgodności spawalniczych dotyczących geometrii i nieciągłości metalu spoiny na przekroju złącza spawanego. Wszystkie przebadane złącza charakteryzowały się poprawną budową strukturalną.

W obszarze linii wtopienia i strefy wpływu ciepła zarejestrowano nieznaczny spadek twardości, obejmuje on stosunkowo wąskie pasmo, przez co nie ma krytycznego wpływu na właściwości eksploatacyjne złączy spawanych. Osobliwość stali obrabianej termomechanicznie polega m.in. na silnej rekrystalizacji w obszarze SWC. W celu obniżenia negatywnego oddziaływania cyklu cieplnego spawania, należy odpowiednio dobrać poziom energii liniowej spawania. Zaobserwowano wyraźną zależność twardości w SWC od poziomu zastosowanej energii liniowej spawania. Spawanie z energią liniową o wartości 1,12 KJ/mm powoduje spadek twardości w SWC do wartości około $230 \mu \mathrm{HV} 0,1$. Zastosowanie wyższego poziomu energii liniowej spawania tj. 1,42 KJ/mm degraduje materiał SWC w wyższym stopniu powodując spadek twardości do około $200 \mu \mathrm{HV} 0,1$. Uzyskane wyniki wskazują na konieczność ustalenia bezpiecznego progu wartości stosowanej energii liniowej spawania, opartego na dodatkowych pomiarach udarności w SWC.

Przeprowadzone badania mikroskopowe złączy spawanych wykazały w spoinie typową strukturę bainityczno - ferrytyczną o charakterze dendrytycznym (pierwotnym). Strefa wpływu ciepła charakteryzuje się obszarami o zmiennej wielkości ziarna, wywołanej oddziaływaniem cyklu cieplnego. W SWC oraz w materiale rodzimym zaobserwowano obecność faz mikrododatków umacniających.

\section{Literatura}

[1] A. Krajewski, W. Włosiński, T. Chmielewski, P. Kołodziejczak „Ultrasonic-vibration assisted arc-welding of aluminum alloys" Bulletin of the Polish Academy of Sciences: Technical Sciences vol. 60 (4), 841-852, 2012.

[2] J. Górka, S. Stano „Własności i struktura złączy spawanych hybrydowo HLAW (wiązka laserowa-FCAW) stali obrabianej termomechanicznie S700MC" Przegląd Spawalnictwa, vol. 85 (5), 54-58, 2015.

[3] W. Wlosinski, T. Chmielewski „Plasma-Hardfaced Chromium Protective Coatings - Effect of Ceramic Reinforcement on Their Wettability by Glass” Adv. Sci. Technol. Vol. 32, 253-260, 2002.

[4] T. Chmielewski, M. Węglowski „Analiza rynku spawalniczego w Polsce pod względem sprzedaży urządzeń oraz materiałów spawalniczych" Przegląd Spawalnictwa Vol. 82 (6), 28-31, 2010.

[5] M. Węglowski, T. Chmielewski, K. Kudła „Porównanie wybranych właściwości nowoczesnych spawalniczych inwertorowych źródeł energii przeznaczonych do spawania metodą MAG" Przegląd Spawalnictwa Vol. 81 (10), 81-83, 2009.

[6] T. Chmielewski „Projektowanie procesów technologicznych - Spawalnictwo" Oficyna Wydawnicza Politechniki Warszawskiej, 2013.

[7] M. Węglowski, B. Jaeschke, T. Chmielewski „Stan obecny i perspektywy rozwoju dynamicznej regulacji źródeł prądu do spawania GMA" Przegląd Spawalnictwa Vol. 87 (10), 130-134, 2015.

[8] J. Górka „Spawalność stali obrabianej termomechanicznie o wysokiej granicy plastyczności" Biuletyn Instytutu Spawalnictwa, nr 5/2010, s. $165-169$.

[9] J. Górka "Właściwości spoin stali obrabianych termomechanicznie o wysokiej granicy plastyczności" Przegląd Spawalnictwa, Vol. 83, No 12, s.31-35, 2011.

[10] D. Fydrych, J. Łabanowski, G. Rogalski „Weldability of high strength steels in wet welding conditions" Polish Maritime Research 20 (2), 67-73, 2013.

[11] D. Fydrych, J. Łabanowski, G. Rogalski, J. Haras, J. Tomków, A. Świerczyńska, P. Jakóbczak, Ł. Kostro "Weldability of S500MC steel in underwater conditions", Advances in Materials Science, vol. 14, no 2 , 37-45, 2014.

[12] N. Yurioka "TMPC steels and their welding" Welding in the World. Vol. 35, 6/1995.

[13] J. Górka „Własności i struktura złączy spawanych stali obrabianej termomechanicznie o wysokiej granicy plastyczności" Wydaw. Politechniki Śląskiej, 2013.

[14] E. Tasak "Spawalność stali" Fotobit, Kraków 2002.

[15] T. Chmielewski, J. Szulc, Z. Pilat „Badania metalograficzne spoin wykonanych hybrydową metodą PTA+MAG" Przegląd Spawalnictwa, Vol. 86, (7), 46-50, 2014. 